Volume 9

Number 12009

December 2009

\title{
Defending Unborn Orphans: Embryo Adoption
}

Krisitn Colman

Cedarville University

DigitalCommons@Cedarville provides a publication platform for fully open access journals, which means that all articles are available on the Internet to all users immediately upon publication. However, the opinions and sentiments expressed by the authors of articles published in our journals do not necessarily indicate the endorsement or reflect the views of DigitalCommons@Cedarville, the Centennial Library, or Cedarville University and its employees. The authors are solely responsible for the content of their work. Please address questions to dc@cedarville.edu.

\section{Recommended Citation}

Colman, Krisitn (2009) "Defending Unborn Orphans: Embryo Adoption," CedarEthics: A Journal of Critical Thinking in Bioethics: Vol. 9 : No. 1 , Article 2. 


\title{
Defending Unborn Orphans: Embryo Adoption
}

Browse the contents of this issue of CedarEthics: A Journal of Critical Thinking in Bioethics.

\begin{abstract}
When parents have a baby, they are required by law and social precedent to care for the baby and provide it with a good home; unless their baby is an excess embryo produced from in vitro fertilization (IVF). Then the embryo can be abandoned to indefinite freezing. However, some families are choosing to adopt these embryos fixed in cryogenic limbo. In this article, I will look at the history and legality of embryo adoption, explain what is involved in embryo adoption, and finally expound on the ethical ramifications of choosing embryo adoption.
\end{abstract}

Keywords

Embryo adoption, ethics

\section{Creative Commons License}

(ब) (1) (3)

This work is licensed under a Creative Commons Attribution-Noncommercial-No Derivative Works 3.0 License.

Follow this and additional works at: http://digitalcommons.cedarville.edu/cedarethics

Part of the Bioethics and Medical Ethics Commons 


\title{
Defending Unborn Orphans: Embryo Adoption
}

\author{
Kristin Colman \\ Cedarville University
}

$\mathrm{W}$ hen parents have a baby, they are required by law and social precedent to care for the baby and provide it with a good home; unless their baby is an excess embryo produced from in vitro fertilization (IVF). Then the embryo can be abandoned to indefinite freezing. However, some families are choosing to adopt these embryos fixed in cryogenic limbo. In this article, I will look at the history and legality of embryo adoption, explain what is involved in embryo adoption, and finally expound on the ethical ramifications of choosing embryo adoption.

During IVF, embryos are created in a petri dish for implantation. To insure sufficient viable embryos for the first and subsequent implantation attempts, excess embryos are produced, with the surplus stored in embryo cryopreservation. The embryos are gradually frozen over approximately 3 hours in cryoprotectant, destined for long term storage in liquid nitrogen at $-196^{\circ} \mathrm{C}$ (Embryo Freezing \& Thawing, 2009). Due to increasingly nuanced storage and freezing techniques, there are comparable results for pregnancy using frozen embryos compared to initial, unfrozen embryos. According to a 2007 study, there is a $35 \%$ chance of carrying a frozen embryo to term (Nightlight Christian Adoptions, 2009). Embryo cryopreservation technology has been widely utilized since the first baby was born from a frozen embryo in 1984 (Embryo Freezing \& Thawing, 2009). As IVF became more readily available the number of frozen embryos increased, and currently there are approximately 500,000 frozen embryos in the United States (Snowflakes, 2009).

The legal status of these frozen embryos is debatable. The Food and Drug Administration has only minimal regulations concerning frozen embryo storage and transfer, so much debate remains in the legal arena. Due to legal precedent set by key Supreme Court rulings on abortion, it is impossible to classify embryos as constitutionally protected full-persons (Brakman \& Weaver, 2007). Therefore, the courts generally classify embryos as property, subsequently controlled by property laws and contracts concerning transfer of ownership. However, due to the lack of Supreme Court precedent for embryos specifically, each state may determine how it will legally categorize embryos. Most states do treat them as a sort of property, but some states have labeled them "special property" to attempt increased regulation of their transfer, although embryo transfer is only infrequently called "adoption." Only Virginia and New York have labeled them "pure personal property." To add to the confusion, states may also individually determine when transfer of parentage occurs: with the transfer of embryo ownership, implantation, or birth (Brakman \& Weaver, 2007).

There are currently several avenues for a family who wishes to pursue embryo adoption, including acquiring embryos directly from a fertility clinic or through an adoption agency. Embryos acquired from a fertility clinic are generally anonymously donated in a closed adoption type scenario. In contrast, an adoption agency would tend to favor a more open adoption type of

CedarEthics, vol. 9, no. 1, pp. 5-8. ISSN 2333-9713

(C) 2009, Kristin Colman, licensed under CC BY-NC-ND

(http://creativecommons.org/licenses/by-nc-nd/3.0/) 
transaction, with at least some interaction between the genetic family and adopted family (Snowflakes, 2009). There are several reputable embryo adoption agencies, and the government has grants promoting embryo adoption awareness and support. However, it is important to note that although many embryos have been adopted, the process does not always result in a baby due to the failure rate of implantation.

The ethical issue that arises with embryo adoption is whether or not embryos need to be adopted. If they are only masses of cells or tissue, then all argument is a moot point: the embryos may be destroyed without guilt. However, pro-life advocates take issue with this stance, and are generally supportive of the embryo adoption movement. For those who believe that personhood begins at conception, the destruction of embryos equals murder before implantation. However, this argument is juxtaposed against natural law, which stands against unnatural, extra-uterine IVF and implantation. Therefore, provision of a womb through adoption is not clearly the ethically correct decision, but such a choice saves an embryo from almost certain destruction.

Although many pro-life advocates applaud life-saving embryo adoption, it is still questionable if this form of adoption is the most morally responsible. There are currently untold numbers of already born children waiting to be adopted around the world. The choice to adopt an embryo instead of pursuing traditional adoption means that a child, perhaps living in awful conditions, will remain an orphan. The ethical decision is further complicated by the seemingly selfish reason many infertile families adopt embryos instead of live children: they want to experience the joy of pregnancy for themselves (Snowflakes, 2009). They may also want more control over what the child is exposed to during pregnancy and early life, therefore ensuring a "better" child. It is important to not selfishly (and unethically) forsake the children needing traditional adoption in favor of the more easily controlled embryo adoptions.

It is also ethically inappropriate to treat embryos as commodities, just as it would be morally wrong to treat babies as property. Society tends to view children as a kind of consumer product (Shuman \& Volck, 2006). This is no different with embryo adoption, in which prospective parents may screen embryo donors for desirable characteristics, leading some to claim that embryo adoption encourages the ethically questionable prospect of "designer babies." The issue of treating embryos as commodities is combated by not allowing the exchange of money for embryos, although the law does classify them as property (Brakman \& Weaver, 2007). In addition, the embryo adoption community has distanced itself from the idea of surrogacy; instead, they utilize the laws governing adoptions. As positive as these safeguards are, however, embryo adoption is still extremely expensive, limiting who is able to take part. Embryo adoption costs through an adoption agency are about $\$ 12,000$ to $\$ 13,000$, plus the additional medical expenses for implantation of the embryos and subsequent prenatal health care (Snowflakes, 2009). Because of the high price to adopt through this avenue, questions have been raised as to whether embryo adoption is a just practice, and if it is appropriate resource stewardship. The price does limit who may adopt, and again makes the embryo appear to be a purchased commodity. Embryo adoption is also frequently pursued as a form of medical intervention for infertility, and subsequently some argue it should be more readily accessible for people of varying socioeconomic levels. The justice of the current practice of embryo adoption is in question. 
Although families from a variety of backgrounds participate in embryo adoptions, for Christians, there is certainly a biblical precedent for protecting orphans (Holy Bible, New Living Translation):

- Exodus 22:22-23 - Never take advantage of any widow or orphan. If you do and they cry out to me, you can be sure that I will hear their cry.

- James 1:27 - Pure and genuine religion in the sight of God the Father means caring for orphans and widows in their distress and refusing to let the world corrupt you.

- Isaiah 1:17 - Learn to do good. Seek justice. Help the oppressed. Defend the cause of orphans. Fight for the rights of widows.

- Proverbs 31:8-9 - Speak up for those who cannot speak for themselves; ensure justice for those being crushed. Yes, speak up for the poor and helpless, and see that they get justice.

- Matthew 25:40 - I tell you the truth, when you did it to one of the least of these my brothers and sisters, you were doing it to me!

Obviously, God expects his followers to care for orphans, which may include the unborn. Many Christian families who choose embryo adoption do so because they recognize the sanctity of life in these little embryos, and wish to protect them from destruction. It is important that they prayerfully consider their choice and the ethical ramifications which surround it. In response, hopefully the church will not judge the adoptive parents' unconventional adoption procedure, but support the desire to care for orphans. Although IVF may be controversial in some denominations, loving babies, regardless of the method of conception, is always the correct response. Surely, God loves all of his children, including both born and unborn orphans.

\section{References}

Brakman, S., \& Weaver, D. (2007). The Ethics of Embryo Adoption and the Catholic Tradition. Springer.

Embryo Freezing \& Thawing. (2009). Retrieved November 3, 2009, from IVF Tutorials: http://www.ivf. net/ivf/embryo_freezing_thawing-o2114.html.

Nightlight Christian Adoptions. (2009). Embryo Donation and Adoption 101. Retrieved November 3,

2009, from Embryo Adoption Awareness Campaign:

http://www.embryoadoption.org/files/embryo_donation_adoption_101.pdf.

Shuman, J., \& Volck, B. (2006). Reclaiming the Body: Christians and the Faithful Use of Modern Medicine. Grand Rapids, MI: Brazos Press.

Snowflakes Frozen Embryo Adoption Program. (2009). Retrieved November 3, 2009, from Nightlight Christian Adoptions Agency: http:/www.nightlight.org/adoptionservices/snowflakes-embryo/adopting-parents.aspx. 
The Holy Bible, New Living Translation. (2005). Tyndale House Publishers. 